\title{
(2) OPEN ACCESS \\ A Patient with speechlessness and rhabdomyolysis: a rare presentation of severe hypocalcaemia
}

\author{
Florine Helene Jiwa, Kim van den Hoek, Clementine Jaantje Joanna van Zeijl, \\ Albertus Jozef Kooter
}

Internal Medicine, Amsterdam UMC Locatie VUmc, Amsterdam, Noord-Holland, The Netherlands

Correspondence to

Dr Albertus Jozef Kooter; JKooter@vumc.nl

Accepted 17 November 2020

Check for updates

(c) BMJ Publishing Group Limited 2020. Re-use permitted under CC BY-NC. No commercial re-use. See rights and permissions. Published by BMJ.

To cite: Jiwa $\mathrm{FH}$

van den Hoek K, van Zeijl CJJ, et al. BMJ Case Rep

2020;13:e238072

doi:10.1136/bcr-2020-

238072

\section{SUMMARY}

A 29-year-old man with no medical history presented to our emergency department with episodes of sudden speechlessness, hoarseness, vomiting after drinking cold water and spasms of his hands. Chvostek's and Trousseau's signs were both seen at presentation. Blood tests revealed severe hypocalcaemia $(1.03 \mathrm{mmol} / \mathrm{L})$ and rhabdomyolysis (creatine kinase (CK) of $2962 \mathrm{IU} / \mathrm{L}$ ). The patient was treated immediately with calcium intravenously with an almost immediate improvement of his voice and quick normalisation of his CK. Additional investigation showed primary hypoparathyroidism in the presence of a vitamin D deficiency, requiring lifelong treatment with calcium supplements and alphacalcidol. Severe hypocalcaemia can be life threatening and prompt treatment is essential. This case reports the unusual first presentation of hypocalcaemia via speechlessness and vomiting together with rhabdomyolysis. Identifying an atypical presentation of hypocalcaemia is critical, for it can be lifesaving.

\section{BACKGROUND}

Calcium plays an essential role in maintaining a normal function of muscles and nerves. For instance, hypercalcaemia can lead to muscle weakness, whereas hypocalcaemia leads to neuromuscular hyperexcitability, often referred to as tetany. ${ }^{1}$ However, even in severe hypocalcaemia, tetany can be absent or not the presenting symptom, as was seen in our patient, leading to unrecognised hypocalcaemia and often a delay in treatment. Untreated, hypocalcaemia can cause a prolonged QT interval leading to dysrhythmias and even cardiac arrest. ${ }^{2}$

The presenting symptoms of our patient were speechlessness, a hoarse voice and vomiting, especially after drinking cold water, which are rare first presentations of hypocalcaemia. Therefore, we aim to increase the knowledge of physicians about the diverse presentation of hypocalcaemia, leading to a better understanding and quicker recognition of this potential deadly metabolic disorder.

\section{CASE PRESENTATION}

A 29-year-old man presented to the emergency room of our hospital with problems of brief episodes of sudden speechlessness and hoarseness. Since 3 months, he noticed a progressively hoarse voice when talking to his passengers or became even speechless for several seconds. During these episodes, he also experienced dyspnoea. Additionally, he reported problem of vomiting, particularly after swallowing cold water. Further questioning revealed progressive spasms of his hands, often during driving, of such severity that his hands were cramped around his steering wheel without the ability to loosen them.

At presentation in our hospital, the hoarseness and sudden disappearance of speech were present up to eight times a day during each time around $30-40$ s. He did not experience paresthesias or seizures. This was the first time he experienced these episodes. No developmental abnormality or other relevant medical, family history or history of substance abuse was reported. General physical and neurological examination showed no abnormalities except for a positive Chvostek's and Trousseau's sign (see figure 1).

\section{INVESTIGATIONS}

Blood tests at presentation showed a severe low total calcium $(1.03 \mathrm{mmol} / \mathrm{L}$; reference range 2.2-2.6), normal albumin $(40 \mathrm{~g} / \mathrm{L}$; reference range $35-55)$, raised phosphate $(2.21 \mathrm{mmol} / \mathrm{L}$; reference range 0.70-1.40), raised CK (2962 IU/L; reference range $<170)$ and low magnesium $(0.58 \mathrm{mmol} / \mathrm{L}$; reference range $0.7-1.0)$ with normal kidney and liver function tests. Later blood tests showed hypoparathyroidism $(0.7 \mathrm{pmol} / \mathrm{L}$; reference range $2-7)$ and low 25-hydroxy(OH)-vitamin D3 concentrations (11 nmol; reference range 50-100). ECG showed a prolonged QTc interval of $501 \mathrm{~ms}$.

Further investigations of his hypoparathyroidism showed no mutations of the calcium-sensing receptor (CaSR) and no parathyroid antibodies.

\section{DIFFERENTIAL DIAGNOSIS}

The initial presentation of a hoarse voice combined with vomiting and spasms was first associated with a neurological or electrolyte disorder. However, during further investigations, a Trousseau's and Chvostek's signs were seen accompanied by spasms of his hands. Since both are characteristic of hypocalcaemia, an electrolyte disorder was more likely, as confirmed by his blood test. Numerous causes can induce hypocalcaemia, so further investigations were warranted. Our differential diagnosis of hypocalcaemia consisted of malnutrition, chronic kidney failure, magnesium depletion, vitamin D deficiency, rhabdomyolysis and hypoparathyroidism. No malnutrition was seen, and blood tests showed normal kidney function. Magnesium depletion was briefly considered as a possible cause. However, symptoms of hypomagnesaemia mostly occur when levels are below $0.4 \mathrm{mmol} / \mathrm{L}$. Although 


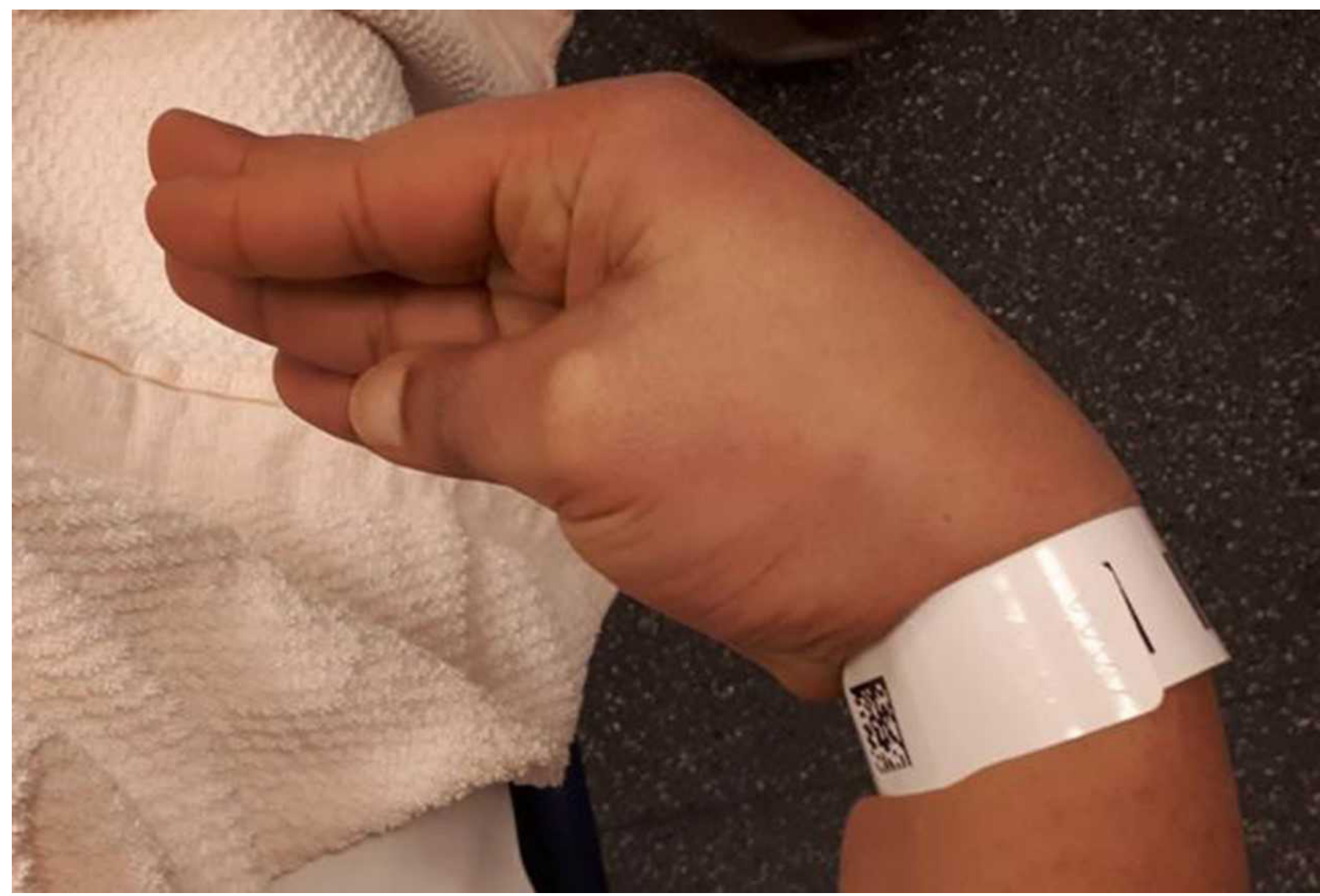

Figure 1 Trousseau's sign. Presentation at the emergency department of our patient with hypocalcaemia-induced spasms of his hand and wrist due to neuromuscular irritation through brachial artery occlusion.

rhabdomyolysis was present, it was not severe enough to explain this hypocalcaemia.

Since a hyperphosphataemia was present as well, hypoparathyroidism seemed most plausible, which was confirmed by a severely decreased parathyroid hormone (PTH) concentration. Additionally, vitamin D deficiency was present. However, this was not considered to cause his hypocalcaemia for raised PTH levels should be present, which was not the case.

These blood tests, together with no medical or surgical history, made a diagnosis of primary hypoparathyroidism with a concomitant vitamin D deficiency most likely. We considered autoimmune hypoparathyroidism or a mutation in the CaSR as a cause of his hypoparathyroidism. However, both tests were negative, resulting in the final diagnosis of idiopathic primary hypoparathyroidism.

\section{TREATMENT}

Immediate treatment with calcium gluconate and magnesium sulphate intravenously was given in the emergency department while monitoring the patient's heart. Quickly after administration of calcium, his voice improved.

We admitted the patient to the acute care unit where he continued to receive calcium intravenously together with alphacalcidol $(1 \mu \mathrm{g})$ since his blood test showed hypoparathyroidism and cholecalciferol orally to restore his vitamin D concentration. After 24 hours, he received $20 \mathrm{mmol}$ calcium in total, which resulted in plasma calcium of $1.57 \mathrm{mmol} / \mathrm{L}$ (reference range: $2.20-2.65 \mathrm{mmol} / \mathrm{L}$ ) and a normal QTc interval. He was transferred to the hospital ward where he continued to receive calcium ( $10 \mathrm{mmol} / 24$ hours) intravenously and alphacalcidol ( $1 \mathrm{ug}$ ) orally. After 5 days, his plasma calcium normalised $(2.15 \mathrm{mmol} / \mathrm{L})$ together with normalisation of his creatine kinase level, and he was discharged.

\section{OUTCOME AND FOLLOW-UP}

Our patient was diagnosed with idiopathic primary hypoparathyroidism for which life-long treatment with calcium supplements and alphacalcidol was prescribed. Since there was a vitamin D deficiency present, he received vitamin D supplements as well. At 2 weeks after discharge, the patient was able to return to his work as a taxi driver.

Follow-up was needed at 1 week, 1 month and every 2 months thereafter in the first year after discharge, on which his calcium, vitamin D levels and urine were checked. Calcium levels above $2.10 \mathrm{mmol} / \mathrm{L}$ were aimed for. However, during follow-up, our patient experienced adherence problems, resulting in hypocalcaemia and again rhabdomyolysis, both normalising after intensification of his treatment. Further follow-up 2 years after hospitalisation showed better adherence with normal plasma calcium and CK concentrations. As well, no vitamin D deficiency or toxicity, or hypercalciuria were seen during follow-up.

\section{DISCUSSION}

We present a patient with a plethora of peculiar findings caused by hypocalcaemia. The most striking symptoms were 
his hoarse voice and episodes of complete speechlessness, indicating an atypical presentation of laryngospasm or spasm of vocalising muscles due to severe hypocalcaemia.

Hypocalcaemia causes neuromuscular irritability, which can manifest as muscle cramps and paraesthesia of the hand and feet and in severe cases as carpopedal spasms, laryngospasms and seizures. ${ }^{3}$ Laryngospasm, usually presenting with dyspnoea and stridor, is a rare but known and lifethreatening sequela of hypocalcaemia traditionally seen in infants. ${ }^{45}$ Stridor and dyspnoea have been described in adults as well. ${ }^{67}$ However, both cases presented patients with stridor and non-specific problems of the throat, like hoarseness, were not described.

Another striking symptom our patient presented with were oesophageal spasms, leading to direct vomiting after drinking cold water. To the best of our knowledge, oesophageal spasms have not been described before in patients with severe hypocalcaemia. Those spasms are probably the result of neuromuscular irritability of the oesophagus triggered by the ingestion of cold water.

Our patient presented with more peculiar findings that require some additional attention.

First, our patient presented a concomitant rhabdomyolysis which resolved after treatment of his hypocalcaemia, suggesting the hypocalcaemia caused his rhabdomyolysis whereas his (moderate) physical exercise may have aggravated muscle cell loss. Our hypothesis was supported by repeated episodes of hypocalcaemia during follow-up, all accompanied by rhabdomyolysis, disappearing after normalisation of plasma calcium.

One might speculate that increased levels of muscle enzymes are associated with muscle cell damage through the ischaemia that occurs in tetanic spasms as a result of hypocalcaemia. This phenomenon has indeed been described in patients suffering from tetanus. ${ }^{8}$ However, the mechanisms of raised CK concentrations due to hypocalcaemia are not well understood, since not all patients with hypocalcaemia develop clinically evident myopathy. ${ }^{9-11}$

Second, hypomagnesaemia was present, which could have contributed to the severeness of his hypocalcaemia. Hypomagnesaemia can induce PTH resistance and diminish its secretion, impairing PTH release in response to hypocalcaemia even more. ${ }^{12}$ However, low PTH can also induce hypomagnesemia in return. Nevertheless, symptoms like laryngospasm will present more likely when both cations are low. ${ }^{13}$ Therefore, the substitution of magnesium besides calcium aids in both calcium and magnesium concentrations, resulting in quicker resolution of symptoms. ${ }^{14}$

Third, we expected a high 25-OH-vitamin D3 concentration due to the lack of parathyroid activity, since PTH assists in the hydroxylation of 25-OH-vitamin D3 to its active form, 1,25-(OH)2 D3. Therefore, a buildup of 25-OH-vitamin D3 was expected. However, this was not the case. His vitamin D deficiency was probably the result of a shortage of daily sunlight, being seated behind the glass of his taxi, combined with a pigmented skin. Vitamin D was supplemented during hospitalisation and after discharge. Combining alphacalcidol and cholecalciferol long term can induce vitamin D toxicity. Therefore, close monitoring of his vitamin D levels during follow-up is essential.

Finally, his urine was routinely checked since calcium can be lost in the urine due to low PTH levels, causing hypercalciuria and possibly resulting in nephrolithiasis. Therefore, the assessment of urine during follow-up is necessary.
This case reports the unusual first presentation of hypocalcaemia via speechlessness, hoarseness and vomiting. It shows the importance of bearing an electrolyte disorder in mind when a patient presents with these symptoms since identifying an atypical presentation of hypocalcaemia can be lifesaving.

\section{Patient's perspective}

At first, I was stunned by everything that happened. When I came to the hospital for my minor complaints, I never suspected I had a serious illness. I always thought of myself to be a healthy person. I was still working daily and was even working out for four or even five times a week, both without any trouble. However, immediate treatment was necessary and I had to stay in the hospital. At this moment I finally understood something was really wrong. They explained everything perfectly to me, which made me feel more at ease.

My treatment was started immediately and within an hour I noticed the cramps in my hands and hoarse speech began to disappear. This made me feel confident in the treatment and the doctors who took care of me. The next days in the hospital went by quickly without any symptoms and I was well-taken care off.

However, on the day of discharge it became apparent that I had to take calcium pills for the rest of my life. I was quite shocked I had to take pills. Before my hospitalisation, I never took any pills and now I had to take them every day. During the first year I sometimes forgot to take my pills for several days. During these periods I again experienced mild cramps in my hands and a tingling sensation in my throat. The recurrence of my symptoms made me aware of the necessity of those pills. Nowadays, I hardly think of the pills as they are part of my daily routine.

I do not like to wonder what would have happened if I did not go to the hospital but on vacation instead, which I had planned. I am very relieved I went to the hospital directly without further delay in treatment.

Overall this whole experience was very strange to me, but my doctors made it easier for me to comprehend and to adhere to take my pills. I am glad about the time they took to explain everything to me. Lastly, I am pleased about all the things I have learned about my own body. I am more aware of the importance of a well-functioning body and how easily it can malfunction.

\section{Learning points}

- Hypocalcaemia often presents with tetanic spasms. However, hoarseness and an inability to speak can be the first presentation of severe hypocalcaemia as well.

- Consider hypocalcaemia as a cause for unexplained vomiting and rhabdomyolysis.

- Unrecognised hypocalcaemia can delay treatment with a potentially fatal outcome.

Contributors FHJ drafted the manuscript. KvdH, CJJvZ and AJK supervised writing of this manuscript. All authors have read and approved the final version.

Funding The authors have not declared a specific grant for this research from any funding agency in the public, commercial or not-for-profit sectors.

Competing interests None declared.

Patient consent for publication Obtained.

Provenance and peer review Not commissioned; externally peer reviewed. 
Open access This is an open access article distributed in accordance with the Creative Commons Attribution Non Commercial (CC BY-NC 4.0) license, which permits others to distribute, remix, adapt, build upon this work non-commercially, and license their derivative works on different terms, provided the original work is properly cited and the use is non-commercial. See: http://creativecommons.org/ licenses/by-nc/4.0/.

\section{REFERENCES}

1 Cooper MS, Gittoes NJL. Diagnosis and management of hypocalcaemia. BMJ 2008;336:1298-302.

2 Meyer T, Ruppert V, Karatolios K, et al. Hereditary long QT syndrome due to autoimmune hypoparathyroidism in autoimmune polyendocrinopathy-candidiasisectodermal dystrophy syndrome. J Electrocardiol 2007;40:504-9.

3 Giusti F, Brandi ML. Clinical presentation of hypoparathyroidism. Front Horm Res 2019;51:139-46.

4 Sharma D, Pandita A, Pratap OT, et al. Laryngospasm and neonatal seizure due to hypocalcaemia and vitamin D deficiency: an emergency condition in NICU and challenge to the neonatologist. BMJ Case Rep 2014;2014. doi:10.1136/bcr-2014206795. [Epub ahead of print: 26 Nov 2014].
5 Murphy G, Bartle S. Hypocalcemic laryngospasm and tetany in a child with renal dysplasia. Pediatr Emerg Care 2006;22:507-9.

6 Srivastava A, Ravindran V. Stridor secondary to hypocalcemia in the elderly: an unusual presentation. Eur J Intern Med 2008;19:219-20.

7 Büyükcam F, Sönmez FT, Sahinli H. A delayed diagnosis: stridor secondary to hypocalcemia. Int J Emerg Med 2010;3:461-2.

8 Weiss MF, Badalamenti J, Fish E. Tetanus as a cause of rhabdomyolysis and acute renal failure. Clin Nephrol 2010;73:64-7.

9 Dai CL, Dai C, Sun ZJ, Zhang X, et al. Elevated muscle enzymes and muscle biopsy in idiopathic hypoparathyroidism patients. J Endocrinol Invest 2012;35:286-9.

10 Ishikawa T, Inagaki H, Kanayama M, et al. Hypocalcemic hyper-CK-emia in hypoparathyroidism. Brain Dev 1990;12:249-52.

11 Akmal M. Rhabdomyolysis in a patient with hypocalcemia due to hypoparathyroidism. Am J Nephrol 1993;13:61-3.

12 Chase LR, Slatopolsky E. Secretion and metabolic efficacy of parthyroid hormone in patients with severe hypomagnesemia. J Clin Endocrinol Metab 1974;38:363-71.

13 Papaioannou A, Papantonaki S, Nyktari V, et al. Hypomagnesaemia associated with diabetes mellitus may cause laryngospasm. Acta Anaesthesiol Scand 2006;50:512-3.

14 Wilson RB, Erskine C, Crowe PJ. Hypomagnesemia and hypocalcemia after thyroidectomy: prospective study. World J Surg 2000;24:722-6.

Copyright 2020 BMJ Publishing Group. All rights reserved. For permission to reuse any of this content visit

https://www.bmj.com/company/products-services/rights-and-licensing/permissions/

BMJ Case Report Fellows may re-use this article for personal use and teaching without any further permission.

Become a Fellow of BMJ Case Reports today and you can:

- Submit as many cases as you like

- Enjoy fast sympathetic peer review and rapid publication of accepted articles

Access all the published articles

- Re-use any of the published material for personal use and teaching without further permission

\section{Customer Service}

If you have any further queries about your subscription, please contact our customer services team on +44 (0) 2071111105 or via email at support@bmj.com.

Visit casereports.bmj.com for more articles like this and to become a Fellow 